\title{
Endothelial Nitric Oxide Synthase 3 (eNOS3) Gene Polymorphisms and Essential Hypertension in Javanese Ethnic Group
}

\section{Polimorfisme Gen Penyandi Endotel Nitic Oxide Synthetase 3 (eNOS3) dan Hipertensi Esensial pada Etnis Jawa}

\author{
Fitranto Arjadi', Saefuddin 'Aziz', Alfi Muntafiah' \\ ${ }^{1}$ Fakultas Kedokteran Universitas Jenderal Soedirman Purwokerto \\ ${ }^{2}$ Laboratorium Genetika Fakultas Biologi Universitas Jenderal Soedirman Purwokerto
}

\begin{abstract}
Hypertension is still a major public health problem in Indonesia and in several other countries. This disease is caused by multi factorial components involving both environmental and genetic factors. eNOS3 gene is one of the enzymes related to the high prevalence of hypertension. This gene expresses the NOS enzyme which regulates the synthesis of NO. NOS enzyme causes vasodilatation which decreases peripheral resistance and lowers blood pressure. This cross sectional study compared hypertension patients to those with normal blood pressure in the age group of 40-80 years old. The main purpose of this study is to evaluate the influence of eNOS3 gene Glu298Asp allele expression in Javanese ethnic group patients with hypertension. The samples consist of 50 respondents with hypertension and 50 respondents with normotension as control. Data of eNOS3 gene polymorphisms and NO plasma levels from the respondents were analyzed using t-test and chi-square test. Glu298Asp allele genotype variation in eNOS3 gene was detected by PCR-FRLP using primers G894TF and G894TR and the PCR products were cut using Mbol restriction enzymes. Sequencing result of each polymorphism band shows a typical nucleotide sequence compared to the nucleotide sequence of eNOS3 gene in Gen Bank. The results of this study showed no connection between Glu298Asp allele polymorphism in eNOS3 gene with hypertension in Javanese. There was also no relation between eNOS3 gene polymorphisms with high levels of respondents' NO plasma. Average NO plasma level of hypertension patients is 34,53 $\mathrm{mmol} / \mathrm{L}$, whereas average NO level of normal blood pressure is $32,5 \mathrm{\mu mol} / \mathrm{L}$.
\end{abstract}

Keywords: Allele Glu298Asp, eNOS3 gene, G894T, hypertension, Javanese ethnic, NO plasma level

\begin{abstract}
ABSTRAK
Hipertensi masih menjadi masalah kesehatan masyarakat yang utama di Indonesia dan beberapa negara lainnya. Penyakit ini disebabkan multifaktor yang melibatkan faktor lingkungan dan genetik. Gen eNOS3 adalah salah satu enzim yang berhubungan dengan tingginya prevalensi hipertensi. Gen ini menyandi enzim NOS yang mengatur sintesis NO. Enzim NOS menyebabkan vasodilatasi, menurunkan resistensi perifer dan menurunkan tekanan darah. Penelitian ini bersifat cross sectional membandingkan pasien hipertensi dengan pasien normal pada kelompok usia 40-80 tahun. Tujuan utama dari penelitian ini adalah untuk mengevaluasi pengaruh ekspresi gen eNOS3 alel Glu298Asp pada pasien etnis Jawa dengan hipertensi. Sampel terdiri dari 50 responden hipertensi dan 50 responden normotensi sebagai kontrol. Data polimorfisme gen eNOS3 dan kadar NO plasma dari responden dianalisis menggunakan uji t-test dan uji chi-square. Variasi genotipe alel Glu298Asp pada gen eNOS3 dideteksi dengan PCR-FRLP menggunakan primer G894TF dan G894TR dan produk PCRnya dipotong menggunakan enzim restriksi Mbol. Hasil sekuensing dari masing-masing pita polimorfisme menunjukkan urutan nuklotida yang khas jika dibandingkan dengan urutan nukleotida gen eNOS3 di Gen Bank. Hasil penelitian ini menunjukkan tidak ada hubungan antara polimorfisme alel Glu298Asp pada gen eNOS3 dengan kejadian hipertensi pada etnik Jawa. Selain itu juga tidak ada hubungan antara polimorfisme gen eNOS3 tersebut dengan tingginya kadar NO dari plasma responden. Kadar NO plasma dari pesien hipertensi rata-rata adalah 34,53 $\mu$ mol/L, sedangkan responden dengan tekanan darah normal kadar NO rata-rata sebesar 32,5 $\mu \mathrm{mol} / \mathrm{L}$.
\end{abstract}

Kata Kunci: Alel Glu298Asp, etnik Jawa, gen eNOS3, hipertensi, kadar NO plasma

Jurnal Kedokteran Brawijaya, Vol. 28, No. 3, Februari 2015; Korespondensi: Fitranto Arjadi. Fakultas Kedokteran Universitas Jenderal Soedirman Purwokerto, Jl. Gumbreng/JI. Medika Purwokerto Telp (0281) 622022 Email: f.arjadi@yahoo.com 


\section{INTRODUCTION}

Currently hypertension grips around $29,8 \%$ of the Indonesian population (1). This disease caused by multifactorial components involving both environmental and genetic factors. Clinical and experimental studies suggest that more than $90 \%$ of the hypertensive patients around the world suffer from essential hypertension (2). Many genes involved in blood pressure regulation have been screened and recognized as candidates for hypertension, such as endothelial nitric oxide synthase (eNOS) gene. This gene encodes the protein eNOS, the main source of endothelial derived relaxation factor NO under physiological conditions. An association between altered NO metabolism and hypertension has been found both in animal and clinical studies (3-6). Because endothelial NO availability is regulated at the level of synthesis, the eNOS gene is hypothesized to be a candidate for essential hypertension and draws considerable attention in many countries (7-8).

The NOS3 gene is located on chromosome 7q35-36 and consists 26 exons in spans $21 \mathrm{~kb}$. Several studies have been shown three single nucleotide polymorphisms (SNPs) in the NOS3 gene be associated with hypertension, including G894T, T786C and a VNTR in intron (9-12). The G894T polymorphism, a $\mathrm{G}$ to $\mathrm{T}$ conversion at nucleotide position 894 in exon 7, results in a replacement of glutamate by aspartate at codon 298. This variant is not located in any functional consensus sequence, but computer analysis has revealed that the G894T mutation results in a conformational change in the eNOS protein from helix to tight turn [14]. The Asp variant of this polymorphism is associated with, coronary diseases $(14,15)$, hypertension (16) and vascular responsiveness to phenylephrine (17). The Asp variant of this polymorphism is also believed to render the enzyme more susceptible to proteolytic cleavage (18).

Although previous evidence suggests that allelic polymorphism of endothelial NO-synthase (eNOS) may account for a considerable proportion of the risk of development of cardiovascular diseases of complex traits (14), the mechanism of the phenotypic expression of pathologic allelic variants of the eNOS gene in blood pressure traits still remains underexplored. In this study, we performed a carefully conducted family-based association study (90 participants) in Javanese trait in Indonesia. Our main aim was to estimate the effect of polymorphisms in eNOS on essential hypertension susceptibility in Javanese trait.

\section{METHOD}

\section{Study Group and Inclusion Criteria}

Consecutive hypertensive patients $(n=49)$ admitted in the State Hospital of Margono Soekarjo, Purwokerto and Clinical Private Hospital in Purwokerto was selected. The criteria for inclusion were: Javanase race and absence of degenerative, systemic and chronic diseases, myocardial revascularization surgery, coronary angioplasty and previous myocardial infarction. The control group consisted of 49 normotensive individuals. Hypertensive patients were diagnosed after presenting a constant systolic arterial pressure, confirmed in three following measurements, higher than $140 \mathrm{mmHg}$ and a diastolic arterial pressure higher than $90 \mathrm{mmHg}$. All of the procedures, risks and potential benefits were properly explained to all of the patients before they provided formal informed consent. This study with human subjects was approved by the regional bioethics committee at the Government of Indonesia.

\section{Blood Platelet Isolation}

$10 \mathrm{ml}$ of venous blood was taken from every subject in sterile conditions into a Falcon tube containing EDTA potassium salt $(11,7 \mathrm{mM})$ as an anticoagulant (Sarstedt). Plasma and platelets were separated by centrifuging $(1000 \times \mathrm{g})$ of whole blood for $5 \mathrm{~min}$. Platelets remain on the bottom than resuspension in Tyrode buffer containing: $137 \mathrm{mM} \mathrm{NaCl}, 12 \mathrm{mM} \mathrm{NaHCO} 3,2 \mathrm{mM} \mathrm{KCl}, 0,34$ $\mathrm{mM} \mathrm{Na} 2 \mathrm{HPO} 4,1 \mathrm{mM} \mathrm{MgCl}$, 5,5 mM glucose, $5 \mathrm{mM}$ Hepes ( $\mathrm{pH} 7,3)$, containing $0,35 \%$ bovine serum albumin. Plasma in supernatant collected to measure nitrite concentration

\section{DNA Extraction}

Packed cells were lysed with Red Cell Lysis buffer. The solution was centrifuged at $4000 \mathrm{rpm}$ for $15 \mathrm{~min}$ at $4^{\circ} \mathrm{C}$ to pellet out the nucleated cells i.e. WBCs. Nucleated cells were subjected to detergent (10\% SDS) and protease (Proteinase K) treatment in Sodium Chloride-EDTA buffer and left at $37^{\circ} \mathrm{C}$ overnight on a shaker. Subsequently proteins were salted out with $5 \mathrm{M} \mathrm{NaCl}$. Proteins were pelleted out by centrifugation at $4000 \mathrm{rpm}$ at room temperature for $15 \mathrm{~min}$. DNA was precipitated by ethanol addition to the supernatant. DNA isolated is stored in TE buffer and stored at $4^{\circ} \mathrm{C}$ for further use. To measure the concentration and purity of DNA we use spectrophotometer.

\section{Genotype Determination}

A set of primers was designed to amplify a 206 bp fragment including the missense Glu298Asp variant (G894T polymorphism) [5'-CAT GAG GCT CAG CCC CAG3'(forward) and 5'-AGT CAA TCC CTT TGG TGC TCA C3'(reverse)]. Each PCR was carried out by using genomic DNA as the template in final reaction volume of $20 \mu \mathrm{L}$ containing $10 \mathrm{mM}$ Tris chloride $\mathrm{pH} 8,3,50 \mathrm{mM} \mathrm{KCl}, 1,5 \mathrm{mM}$ $\mathrm{MgCl} 2,200 \mu \mathrm{M}$ each of the four dNTPs, $1 \mu \mathrm{M}$ each of the primers, and $2 \mathrm{U}$ Taq DNA polymerase with the following cycling conditions: $94^{\circ} \mathrm{C}$ for $45 \mathrm{~s}, 59^{\circ} \mathrm{C}$ for $30 \mathrm{~s}$, and $72^{\circ} \mathrm{C}$ for $45 \mathrm{~s}$ for 30 cycles in a PTC 100 (MJ research co.) DNA thermal cycler. The PCR fragment digested three hours at $37^{\circ} \mathrm{C}$ with the $\mathrm{Mbol}$ restriction enzyme and then separated by electrophoresis on $5 \%$ agarosa gel and visualized by ethidium bromide.

\section{eNOSActivity}

For an assay of eNOS activity we used a ELISA based on Griess method. Nitrite levels were measured using a commercial Griess reaction kit (Cayman Chemicals, Ann Arbor, MI). The principle of fluorescence of triazolofluoresceine, which is formed after interaction of $\mathrm{NO}$ with 4,5-diaminofluoresceine, which is formed from 4,5-diaminofluoresceine diacetate (DAF-2A) under the action of intracellular esterase. The wave length of excitation/emission was $492 / 515 \mathrm{~nm}$. The NOS inhibitor diphenyliodonium chloride $(100 \mu \mathrm{M})$ inhibited the reaction and this confirms the specificity of the NOS activity assay. Enzyme activity was evaluated in units of fluorescence (UF) per min per 106 cells. In mammals there are few cell types, which express only one isoform of NO synthase. In platelets under normal conditions only endothelial NOS is expressed, which ensures that only the activity of this particular isoform 
was assayed.

\section{Statistical Analysis.}

Data were expressed as means \pm standard deviation (SD), median (inter quartile range), or absolute number (percentage) when appropriate. The t-test for independent samples was used to investigate differences between groups for approximately normally distributed variables. When the distribution of the variables was skewed the non-parametric Mann-Whitney $U$ test was applied.

\section{RESULTS}

Table 1 summarizes the clinical and laboratorial characteristics of the 100 subjects enrolled in the present study. There were no statistically significant differences in gender, between hypertensive groups and the control group (all P N 0,05). Higher systolic and diastolic blood pressure were found in women with gestational hypertension or with preeclampsia compared with the other groups (both $\mathrm{P}$ b 0,05; Table 1).

Table 1. Clinical and laboratorial characteristics of respondent between Hypertension groups and Normotension (control) groups

\begin{tabular}{llrr}
\hline No & Variable & $\begin{array}{r}\text { Hypertension } \\
(\mathbf{n}=\mathbf{5 0})\end{array}$ & $\begin{array}{r}\text { Normotension } \\
(\mathbf{n}=50)\end{array}$ \\
\hline 1 & Gender & $16(32 \%)$ & $16(32 \%)$ \\
& Male & $34(68 \%)$ & $34(68 \%)$ \\
& Female & $60,64 \pm 9,555$ & $56,72 \pm 9,051$ \\
2 & Age (years) & $152,2 \pm 17$ & $124,0 \pm 6$ \\
3 & Systolic & $88,9 \pm 10$ & $79,0 \pm 5$ \\
4 & Diastolic & $112,2 \pm 46$ & $106,1 \pm 42$ \\
5 & GDS & $184,6 \pm 33$ & $180,9 \pm 34$ \\
6 & Cholesterol Total & $160,9 \pm 89$ & $154 \pm 117$ \\
7 & Triglyceride & $34,53 \pm 9,69$ & $32,5 \pm 16$ \\
8 & NO & $14,53 \pm 22$ & $5,9 \pm 3,4$ \\
9 & Angiotensin & & \\
\hline
\end{tabular}

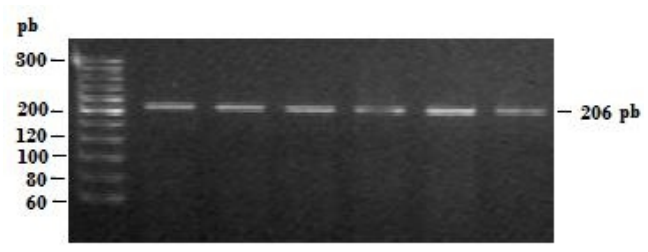

Figure 1. Electroforegram of PCR Product of fragment NOS3 gene

Note: The 206 bp band is the amplification of fragment gene NOS3

Figure 1 showed the result of amplification of fragment NOS3 gene from some genomic DNA samples. A single clear band at $206 \mathrm{bp}$ is strongly indicated that fragment is belong to NOS3 gene regarding the use of specific primers. As a template, genomic DNA from blood is measured both quantity and quality with spectrophotometer. Highly quality DNA showed from the result of absorbency $260 / 280$ close to 1.8 is used in this study (data not presented).

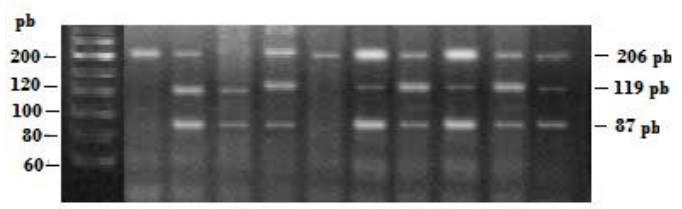

Figure 2. Electroforegram of PCR-RFLP from some samples to detect genotype variation in gene NOS3 with Mbol

Note: In these figures M- marker REF-20; genotype GG cannot cutted and resulted $206 \mathrm{bp}$ band. Genotype TT cutted and resulted two band $119 \mathrm{bp}$ and $87 \mathrm{bp}$, while genotype GT resulted three band from uncut and cut fragment $206 \mathrm{bp}, 119 \mathrm{bp}$ and $87 \mathrm{bp}$. Due to confirming the data, after PCRRFLP finished, some sample than sequenced to EIJKMAN Jakarta. The result of sequencing is than alignment with prefers data NOS3 nucleotide from gene bank

gi|2315713

GCTGCAGGCC CCAGATGATC CCCCAGAACT CTTCCTTCTG CCCCCCGAGC gi|2315713 GCTGCAGGCC CCAGATGATC CCCCAGAACT CTTCCTTCTG CCCCCCGAGC sample 19 GCTGCAGGCC CCAGATGAGC CCCCAGAACT CTTCCTTCTG CCCCCCGAGC sample N2 GCTGCAGGCC CCAGATGATC CCCCAGAACT CTTCCTTCTG CCCCCCGAGC

Figure 3. Sequencing product of genotypic variation on NOS3 gene

Note: Sample 19 and N2 are indicated different genotype. Sample N2 can cut with $\mathrm{Mbol}$ but sample 19 cannot cut. GATC is a cutting site of $\mathrm{Mbol}$. Point mutation in this site make the enzyme cannot work. The gi 2315713 is reference Sequencing of NOS3 gene from Gen bank

The distribution of genotype variation on NOS3 gene from Javanese ethnic presented in Table 2. These data indicated that genotype variation show a great effect on prevalention on hypertension $(\mathrm{OR}=2,945)$. Person with hypertension are dominated in genotype GT with close to $60 \%$, but people with normal blood pressure are dominated in genotype GG with the some portion. On the other hand Genotype TT is very rare in both groups.

Table 2. Genotype and allele frequencies for NOS3 polymorphisms in both hypertension and normotension group

\begin{tabular}{ccrrrrrr}
\hline Polymorphism & $\begin{array}{c}\text { Genotype } \\
\text { or Allele }\end{array}$ & $\begin{array}{c}\text { Hypertension } \\
\mathbf{N}=\mathbf{4 2}\end{array}$ & $\begin{array}{c}\text { Normotensi } \\
\text { on } \\
\mathbf{N = 4 5}\end{array}$ & $\begin{array}{c}\text { OR } \\
\text { (95\% Cl) }\end{array}$ & P \\
\hline G894T & GG & 16 & $38,1 \%$ & 29 & $64,4 \%$ & & \\
& TT & 1 & $2,4 \%$ & 0 & $0 \%$ & & \\
& GT & 25 & $59,5 \%$ & 16 & $35,6 \%$ & 2,945 & 0,014 \\
\hline
\end{tabular}

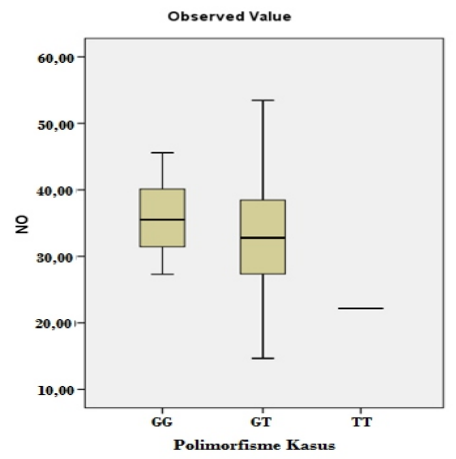

Figure 4: Intergenotypic variations in the levels of nitrite in the study subjects 


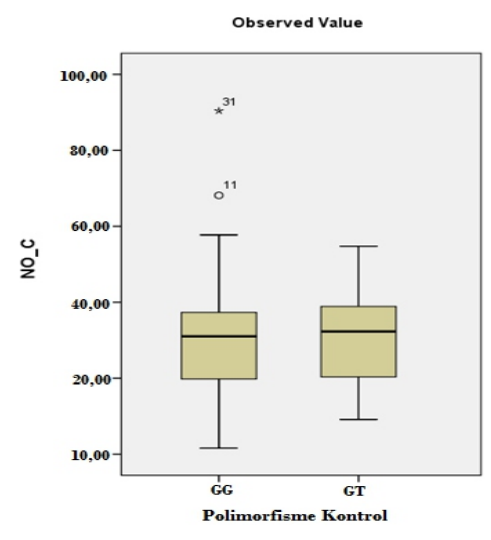

Figure 4: Intergenotypic variations in the levels of nitrite in the study subjects

Figure 4, shows that there was no significant difference in the levels of nitrite between GG and GT genotypes in both patients $(p=0,66)$ and controls $(p=0,46)$. However, in both the genotypes, levels of nitrite were significantly lower in patients than in controls $(p<0,01$ for $a b$ and $p<0,001$ for bb).

\section{DISCUSSION}

The participation of females in this study was nearly threefold than that of the males. This could be due to the social forces in the society where this study was conducted. Another study done in Padang, Sumatra Barat in Minang ethnic populations, with a larger sample size showed the females subjects dominated $78,5 \%$ of distribution than male (19).

The nitrite levels were significantly the same both in patients and controls. The nitrite levels in the patients were 34,53 less higer than that in the controls. Previous

\section{REFERENCES}

1. Badan Penelitian dan Pengembangan Kesehatan Departemen Kesehatan Republik Indonesia. Riset Kesehatan Dasar. Jakarta: Badan Penelitian dan Pengembangan Kesehatan Departemen Kesehatan Republik Indonesia; 2007.

2. Dosh SA. The Treatment of Adults with Essential Hypertension. The Journal of Family Practice. 2002; 51(1): 74-80.

3. Wang HG, Wang JL, Chang P, et al. Endothelial Nitric Oxide Synthase Gene Polymorphisms and Essential Hypertension in Han Chinese. Genetic and Molecular Research. 2010; 9(3): 1896-1907.

4. Kingah PL, Luu HN, Volcik KA, Morrison AC, Nettleton $\mathrm{JA}$, and Boerwinkle E. Association of NOS3 Glu298Asp SNP with Hypertension and Possible Effect Modification of Dietary Fat Intake in the ARIC Study. Hypertension Research. 2010; 33(2): 165-169.

5. Tsutsui $M$, Shimokawa $H$, Otsuji $Y$, Ueta $Y$, Sasaguri $Y$, and Yanagihara N. Nitric Oxide Synthases and Cardiovascular Diseases: Insights from Genetically Modified Mice. Circulation Journal. 2009; 73(6): 986993. studies have shown a very similar results with $43 \%$ decline in patients as compared to controls $(20,21)$. The normal range of NO showed a wide variation in different studies (22-25). No relationship could be found between nitrite levels and gene polymorphism. This study did not find any correlation between the presence of the eNOS variant and hypertension. This may be because of the small sample size. According to the previous literature, only two studies, one on Caucasians in general (26), and another on the Ukrainian population (23), have shown a correlation between this polymorphism and essential hypertension. Other studies have found no such correlation $(27,28)$. Although no statistically significant correlation could be found in the present study, a trend toward a higher frequency of the allele was seen among the patients with essential hypertension. However, this suggests a need to conduct a large cohort study so that the nature of any association between essential hypertension and this polymorphism can be tested. If the allele is found to be a disease-associated allele, screening of the population for individuals at risk might help save lives. If not, we can rule out an association of essential hypertension with this polymorphism. NO levels showed a significant difference between patients and controls. This suggests that an estimation of NO levels could be included as a routine lab investigation to screen people at risk and to devise appropriate individualized therapeutic strategies. However, we stress that the reference value for NO in normal Javanese trait subjects remains to be established. Estimating total NO is rather cumbersome, as it involves converting nitrate back to nitrite using the enzyme nitrate reductase. However, estimation of nitrite alone using an economic and simple method is a workable alternative.

\section{ACKNOWLEDGEMENTS}

This research was funded by RISBIN-IPTEKDOK 2012 Ministry of Health of Indonesia

6. Pyle RL, Abbott J, and MacLean H. Pulmonary Hypertension and Cardiovascular Sequelae in 54 Dogs. International Journal of Applied Research in Veterinary Medicine. 2004; 2(2): 99-109.

7. Kimura L, Angeli CB, Auricchio MTBM, et al. Multilocus Family-Based Association Analysis of Seven Candidate Polymorphisms with Essential Hypertension in an African-Derived Semi-Isolated Brazilian Population. International Journal of Hypertension. 2012; 2012: 8.

8. Pacanowski MA, Zineh I, Cooper-DeHoff RM, Pepine CJ, and Johnson JA. Genetic and Pharmacogenetic Associations between NOS3 Polymorphisms, Blood Pressure, and Cardiovascular Events in Hypertension. American Journal of Hypertension. 2009; 22(7): 748-753.

9. Cruz-González I, Corral E, Sánchez-Ledesma $M$, Sánchez-Rodríguez A, Martín-Luengo C, and GonzálezSarmiento R. Association between -T786C NOS3 Polymorphism and Resistant Hypertension: $A$ Prospective Cohort Study. BMC Cardiovascular Disorders. 2009; 9: 35-42.

10. Wang P, Koehle MS, and Rupert JL. Genotype at the Missense G894T Polymorphism (Glu298Asp) in the NOS3 Gene is Associated with Susceptibility to Acute 
Mountain Sickness. High Altitude Medicine and Biology. 2009; 10(3): 261-267.

11. Mehmetoğlu I, Yilmaz G, Kurban S, Acar H, and Düzenli MA. Investigation of Enos Gene Intron 4 A/B VNTR and Intron 23 Polymorphisms in Patients with Essential Hypertension. Turkish Journal of Medical Sciences. 2010; 40(3): 479-484.

12. Shankarishan P, Borah PK, Ahmed G, and Mahanta J. Prevalence of Endothelial Nitric Oxide Synthase (Enos) Gene Exon 7 Glu298Asp Variant in North Eastern India. Indian Journal of Medical Research. 2011; 133(5): 487-491.

13. Miyamoto $\mathrm{Y}$, Saito $\mathrm{Y}$, Kajiyama N, et al. Endothelial Nitric Oxide Synthase Gene is Positively Associated with Essential Hypertension. Hypertension. 1998; 32(1): 3-8.

14. Yang Y, Du K, Liu Z, and Lu X. Endothelial Nitric Oxide Synthase (eNOS) 4b/a Gene Polymorphisms and Coronary Artery Disease: Evidence from a MetaAnalysis. International Journal of Molecular Science 2014; 15(5): 7987-8003.

15. Casas JP, Cavalleri GL, Bautista LE, Smeeth L, Humphries SE, and Hingorani AD. Endothelial Nitric Oxide Synthase Gene Polymorphisms and Cardiovascular Disease: A HUGE Review. American Journal of Epidemiology. 2006; 164(10): 921-935.

16. Ali AAA, Wassim NM, Dowaidar $M$, and Yaseen AE. Association of eNOS (E298D) and CYP2J2 (-50 G/T) Gene Polymorphisms with Hypertension among Egyptian Cases. The Journal of Basic and Applied Zoology. 2013; 66(4): 234-241.

17. Ormezzano O, Amar J, Vehier CM, et al. Association of Enos Glu298Asp Gene Polymorphism with Circadian Blood Pressure Rhythm. Journal of Human Hypertension. 2007; 21: 501-503.

18. Jáchymová M, Horky K, Bultas J, et al. Association of the Glu298Asp Polymorphism in the Endothelial Nitric Oxide Synthase Gene with Essential Hypertension Resistant to Conventional Therapy. Biochemical and Biophysical Research Communication. 2001; 284(2): 426-430.

19. Sulastri D, Rahmatini, Lipoeto NI, dan Edwar Z. Pengaruh Asupan Antioksidan terhadap Ekspresi Gen eNOS3 pada Penderita Hipertensi Etnik Minangkabau. Majalah Kedokteran Indonesia. 2010;
60(12): 564-570.

20. Afrasyap L and Osturk G. NO Synthese Gene Polymorphism (Glu 298 Asp) in the Patients with Coronary Arthery Disease from Turki Population. Acta Biochimica et Biophisica Sinicia. 2004; 36(10): 661666.

21. Dosenko VE, Zagoriy VY, Haytovich NV, Gordok OA, and Moibenko AA. Allelic Polymorphism of Endothelial NOSynthase Gene and its Functional Manifestations. Acta Biochimica Polonica. 2006; 53(2): 299-302.

22. Ferlito S, Gallina M, Pitari GM, and Bianchi A. Nitric Oxide Plasma Levels in Patients with Chronic and Acute Cerebrovascular Disorders. Panminerva Medica. 1998; 40(1): 51-54.

23. Jeerooburkhan N, Jones LC, Bujac S, et al. Genetic and Environmental Determinants of Plasma Nitric Oxides and Risk of Ischemic Heart Disease. Hypertension, 2001; 38(5): 1054-1061.

24. Klahr S. The Role of Nitric Oxide in Hypertension and Renal Disease Progression. Nephrology Dialysis Transplantation. 2001: 16(1); 60-62.

25. Kumar CA and Das UN. Lipid Peroxides, Antioxidants and Nitric Oxides in Patients with Pre-Eclampsia and Essential Hypertension. Medical Science Monitor. 2000; 6(5): 901-907.

26. Rodríguez-Esparragón FJ, Rodríguez-Pérez JC, MacíasReyes A, and Alamo-Santana F. Peroxisome Proliferator-Activated Receptor-Gamma2-Pro12Ala and Endothelial Nitric Oxide Synthase-4a/B Gene Polymorphisms are Associated with Essential Hypertension. Journal of Hypertension. 2003: 21(9): 1649-1655.

27. Gouni-Berthold I, Giannakidou E, Müller-Wieland D, et al. Peroxisome Proliferator-Activated Receptor[Gamma]2 Pro12Ala and Endothelial Nitric Oxide Synthase-4a/B Gene Polym Orphisms are not Associated with Hypertension in Diabetes Mellitus Type 2. Journal of Hypertension. 2005; 23(2): 301-308.

28. Zhao Q, Su SY, Chen SF, Li B, and Gu DF. Association Study of the Endothelial Nitric Oxide Synthase Gene Polymorphisms with Essential Hypertension in Northern Han Chinese. Chinese Medical Journal. 2006; 119(113): 1065-1071 